\title{
Resistance of Brazilian diamondback moth populations to insecticides
}

\author{
Alexandre Conte de Oliveira'; Herbert Álvaro Abreu de Siqueira ${ }^{1 *}$; José Vargas de \\ Oliveira ${ }^{1}$; Jefferson Elias da Silva ${ }^{1}$; Miguel Michereff Filho ${ }^{2}$ \\ ${ }^{1}$ UFRPE - Programa de Pós-graduação em Entomologia Agrícola, R. Dom Manoel de Medeiros, s/n - 52171-900 - \\ Recife, PE - Brasil. \\ 'Embrapa Hortaliças, Rod. Brasília/Anápolis BR 060, km 09 - C.P. 218 - 70351-970 - Brasília, DF - Brasil. \\ *Corresponding author <siqueira@depa.ufrpe.br>
}

\begin{abstract}
Plutella xylostella is a recurring pest on cruciferous crops around the world. In Brazil, it typically requires large number of insecticide sprays, which may lead to fast evolution of resistance. The aim of this study was to assess the susceptibility of Brazilian diamondback moth populations to the insecticides abamectin, deltamethrin, and spinosad. Leaf dip bioassays were used to determine mortality data obtained after $48 \mathrm{~h}$ of exposure to insecticides and subjected to Probit analysis. The population from Bonito, state of Pernambuco, Brazil, had the highest toxicity ratio (20.2 - fold) to abamectin compared to the reference population. The $\mathrm{LC}_{50}$ values for deltamethrin ranged from 85.2 to $360.1 \mathrm{mg} \mathrm{L}^{-1}$, demonstrating a high survival of populations in relation to this insecticide field dose rate $\left(7.5 \mathrm{mg} \mathrm{L}^{-1}\right)$. The toxicity ratios of the estimated $\mathrm{LC}_{50} \mathrm{~s}$, however, were very low (varying from 2.2 - to 4.2 - fold). Most populations exhibited toxicity ratios for spinosad, ranging from 2.3 - to 5.1 - fold, while both the $\mathrm{LC}_{50}$ and $\mathrm{LC}_{95}$ values reflected a high susceptibility to the spinosad field dosage $\left(120 \mathrm{mg} \mathrm{L}^{-1}\right)$. Only the Bonito - PE population resisted to abamectin, while all $P$. xylostella populations were resistant to deltamethrin, but particularly susceptible to spinosad because of the absence of selection pressure with it in these areas.
\end{abstract}

Key words: Plutella xylostella, Lepidoptera, chemical control, susceptibility

\section{Resistência de populações brasileiras de traça das brássicas a inseticidas}

\begin{abstract}
RESUMO: Plutella xylostella é uma praga recorrente em brássicas de todo o mundo. No Brasil, normalmente exige grande número de pulverizações de inseticidas, que pode levar à rápida evolução da resistência. Avaliouse a suscetibilidade de populações brasileiras da traça das crucíferas aos inseticidas abamectina, deltametrina e espinosade. Bioensaios de imersão de folhas foram utilizados para determinar a mortalidade, sendo os dados obtidos após $48 \mathrm{~h}$ de exposição aos inseticidas e submetidos à análise de Probit. A população de Bonito-PE apresentou a maior razão de toxicidade (20,2 vezes) para abamectina em relação à população de referência. Os valores de $\mathrm{CL}_{50}$ s para deltametrina variaram entre 85,2 - 360,1 $\mathrm{mg} \mathrm{L}^{-1}$, demonstrando alta sobrevivência das populações a este inseticida com relação à dose de campo $\left(7,5 \mathrm{mg} \mathrm{L}^{-1}\right)$. Entretanto, as razões de toxicidade das $\mathrm{CL}_{50}$ estimadas foram muito baixas (variando de 2,2 a 4,2 vezes). A maioria das populações apresentou razões de toxicidade para espinosade, variando de 2,3 para 5,1 vezes, embora os valores de CL demonstram alta suscetibilidade delas à dose de campo para espinosade $\left(120 \mathrm{mg} \mathrm{L}^{-1}\right)$. Apenas a população de Bonito - PE apresentou resistência a abamectina, enquanto todas as populações de $P$. xylostella estão resistentes a deltametrina, mas suscetíveis ao espinosade particularmente devido à ausência de pressão de seleção com este nestas áreas. Palavras-chave: Plutella xylostella, Lepidoptera, controle químico, suscetibilidade
\end{abstract}

\section{Introduction}

The diamondback moth, Plutella xylostella (L.) (Lepidoptera: Plutellidae), ranks in the top 20 most resistant insect species reported so far, which has developed resistance to virtually all insecticide classes (Sarfraz and Keddie, 2005). It is the most important Brassicaceae pest in many parts of the world (Talekar and Shelton, 1993). In Brazil, it occurs year round (Melo et al., 1994), particularly because cruciferous vegetables are usually staggered grown throughout the year. To reduce losses inflicted by the diamondback moth, most farmers have opted for the chemical method, the most used for control (França et al., 1985), which can apparently produce the best results through intensive sprays of insecticides (Castelo Branco et al., 2003). However, this practice has been inefficient over the time because up to four applications a week have apparently not reduced the losses caused by the diamondback moth (Castelo Branco et al., 2001). In many other parts of the world, up to 15 or 20 sprays per season are not uncommon, independently of the pest presence (Guan-Soon, 1990). The indiscriminate use of insecticides in Brazil has contributed to increasing environmental pollution, high levels of residues on products, and intoxication cases (Araújo et al., 2000). In general, these drawbacks are associated with another more aggravating problem, the evolution of insecticide resistance in insect populations (Georghiou, 1983), result-

Sci. Agric. (Piracicaba, Braz.), v.68, n.2, p.154-159, March/April 2011 
ing from high selection pressure with pesticides. In the case of $P$. xylostella, several generations a year and its high migration potential have contributed to faster selection of resistant populations to several classes of insecticides (Sarfraz and Keddie, 2005).

Populations of P. xylostella have a long history of resistance evolution to virtually all classes of insecticides (Khaliq et al., 2007; Shelton et al., 2000; Talekar and Shelton, 1993), including the biological insecticides such as the Bacillus thuringiensis (Berl.) (Shelton et al., 1993). In the recent years, groups of insecticides have been developed and showed excellent activities towards P. xylostella populations resistant to traditional products such as organophosphates, carbamates, and pyrethroids. Among those, the avermectins (França and Medeiros, 1998), insect growth regulators (Oouchi, 2005), emamectin benzoate, spinosad, and indoxacarb (Wilson et al., 2006) are included. But, cases of resistance to these insecticides have already been reported in the literature such as to spinosad (Zhao et al., 2002; Zhao et al., 2006).

The first evidence of resistant populations of diamondback moth to insecticides in Brazil was reported in 1997 for pyrethroids, organophosphates, and B. thuringiensis in the Federal District area (Castelo Branco et al., 1997). Despite that, surveys from other regions do not exist, particularly in the Northeast region where indiscriminate use of pesticides is high and control failures are very common among growers. Therefore, the present work aimed to evaluate the current susceptibility of $P$. xylostella populations to deltamethrin, spinosad, and abamectin. Deltamethrin use has been long in Northeast Brazil to control the diamondback moth and sprays with this insecticide have been nowadays very reduced in the region due to lack of efficacy. The abamectin is not registered to control P. xylostella in Brazil, but farmers use it sporadically in some areas while spinosad is used in a lesser extent because it is costly.

\section{Material and Methods}

Eight populations of diamondback moth from three crucifer-growing regions in Brazil were bioassayed to compare their susceptibility to deltamethrin, abamectin, and spinosad (Figure 1, Table 1). These populations were reared individually in the laboratory in the absence of insecticides treatments, but assayed not beyond the $7^{\text {th }}$ generation. The Chã-Grande I - PE population has been under laboratory rearing with no insecticide selection pressure since 1998 . The $P$. xylostella rearing procedures were based on those described in Barros and Vendramin (1999). Adults were kept in cylinder cages and fed 10\% honey-water. Eggs were collected on collard discs every day and transferred to plastic cages containing organic Brassica oleracea var. acephala fresh leaves. The number of eggs was adjusted to ensure that overcrowding did not occur to reduce the fitness of the larvae. The insecticides used in this study were abamectin, deltamethrin, and spinosad.

Leaf dip bioassays as previously reported (Shelton et al., 1993; Shelton et al., 2000) were used for each population of P. xylostella, but insecticide-free collard (Brassica oleracea var. acephala) leaves were used instead. Concentration-response lines were established with the insecticides abamectin, deltamethrin, and spinosad for the different populations of $P$. xylostella through bioassays to assess mortality. Preliminary assays were done with every insecticide for each population to determine an "all or none" response, i.e., the concentration range where a concentration-response relationship exists.

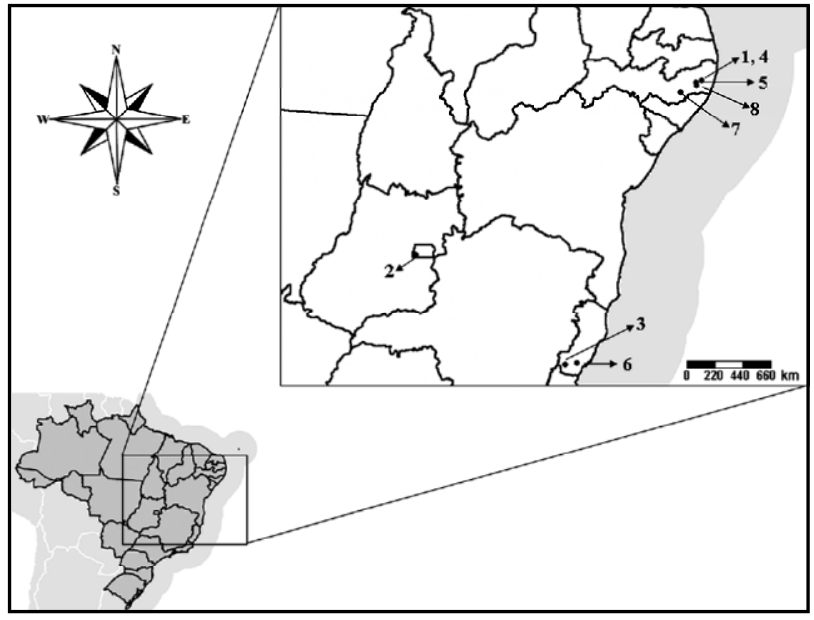

Figure 1 - Site collection of diamondback moth, Plutella xylostella, populations.

Table 1 - Origin and collection year of diamondback moth, Plutella xylostella, populations in Brazil.

\begin{tabular}{|c|c|c|c|c|c|c|}
\hline $\begin{array}{l}\text { Map } \\
\text { Reference }\end{array}$ & State & County & Region & Host & Place & Month and year of collection \\
\hline 1 & Pernambuco & Chã Grande I & Northeast & Cabbage & Laboratory & May 1998 \\
\hline 2 & Distrito Federal & Brasília & Middle west & Cabbage & Laboratory & September 2004 \\
\hline 3 & Espírito Santo & Alegre & Southeast & Collard & Laboratory & November 2006 \\
\hline 4 & Pernambuco & Chã Grande II & Northeast & Cabbage & Field & August 2008 \\
\hline 5 & Pernambuco & Camocin & Northeast & Cabbage & Field & May 2008 \\
\hline 6 & Espírito Santo & Vargem Alta & Southeast & Cabbage & Field & September 2007 \\
\hline 7 & Pernambuco & Garanhuns & Northeast & Cabbage & Field & February 2008 \\
\hline 8 & Pernambuco & Bonito & Northeast & Cabbage & Field & May 2008 \\
\hline
\end{tabular}


Leaves of organic collard were used in the bioassays after sanitization in sodium hypochlorite $(5 \%)$ and thorough rinsing in clean water. Leaf discs of $5 \mathrm{~cm}$ diameter were cut out with a sharp metal cylinder, and dipped for one minute into each concentration, and left to dry at room temperature. Later, discs were transferred into Petri dishes $(60 \times 15 \mathrm{~mm})$, containing filter papers (5 $\mathrm{cm})$ moistened with $\mathrm{H}_{2} \mathrm{O}$. At least seven insecticide concentrations (+Triton $\mathrm{X}-100$ at $0.01 \%$, as spreader) with three replicates were used. The control comprised leaf discs treated with Triton X-100 solution at $0.01 \%$. Following, ten late $2^{\text {nd }}$-instar larvae of $P$. xylostella were transferred to each dish with the aid of a soft brush. The Petri dishes were maintained inside a growth chamber at the temperature of $27 \pm 0.2^{\circ} \mathrm{C}$ and R.H. of $65 \pm 5 \%$. The mortality was evaluated $48 \mathrm{~h}$ after exposure and the bioassays were repeated at least one more time. The mortality criterion was based on the movement of larvae for at least the body length after being prodded by a fine brush (Kabir et al., 1993). When control mortality was greater than $10 \%$, bioassays were discard and repeated. Mortality data were subjected to probit analysis (Finney, 1971) after correction (Abbott, 1925) using the POLOPC program (Leora Software, 1987). Toxicity ratios and their $95 \%$ confidence intervals were calculated following the method described by Robertson and Preisler
(1992), and considered significant $(p<0.05)$ when the confidence interval did not include the value 1.0. The Pearson correlation coefficient ( $r$ ) was used to test the pairwise relationship between the $\log L_{50} \mathrm{~s}$ as well as the $\mathrm{LC}_{95} \mathrm{~s}$ among insecticides (Sokal and Rohlf, 1995) using the PROC CORR (SAS Institute, 2001).

\section{Results and Discussion}

There was a variation in susceptibility among the populations for the insecticides evaluated, based on the inclusion criterion of the value 1.0 in the $95 \% \mathrm{CI}$ of the toxicity ratio (Table 2, 3 and 4). Because of the lack of a general standard susceptible population, toxicity ratios were compared with the most susceptible population for each insecticide. Based on the $\mathrm{LC}_{50}$ estimates for the $P$. xylostella populations, the Chã Grande I-PE population was the most susceptible to the abamectin insecticide (Table 2), while Vargem Alta-ES was the most susceptible to deltamethrin (Table 3), and Garanhuns-PE to spinosad (Table 4).

The $\mathrm{LC}_{50}$ values of abamectin for $P$. xylostella populations varied from 0.007 to $0.136 \mathrm{mg} \mathrm{L}^{-1}$ (Table 2). Among the populations, six showed toxicity ratios to abamectin (2.1 to 20.2 - fold). Only the Bonito - PE population, however, presented a relatively high toxicity ratio (20.2 - fold)

Table 2 - Susceptibility of Plutella xylostella populations to abamectin.

\begin{tabular}{lccccccc}
\hline Population & $\mathrm{n}^{(1)}$ & $\mathrm{DF}^{(2)}$ & Slope $\pm \mathrm{SE}^{(3)}$ & $\mathrm{LC}_{50}(\mathrm{CI} 95 \%) \mathrm{mg} \mathrm{L}{ }^{-1}$ & $\mathrm{LC}_{95}(\mathrm{CI} 95 \%) \mathrm{mg} \mathrm{L}^{-1}$ & $\chi^{2(4)}$ & $\mathrm{TR}^{(5)}\left(\mathrm{CI}_{95} \%\right)^{(6)}$ \\
\hline Chã Grande I-PE & 253 & 5 & $2.12 \pm 0.26 \mathrm{a}$ & $0.007(0.005-0.009)$ & $0.040(0.028-0.068)$ & 2.16 & - \\
Brasília-DF & 293 & 5 & $2.55 \pm 0.27 \mathrm{~b}$ & $0.008(0.007-0.010)$ & $0.036(0.027-0.054)$ & 1.86 & $1.2(0.9-1.7)$ \\
Alegre-ES & 350 & 5 & $1.89 \pm 0.22 \mathrm{a}$ & $0.014(0.011-0.017)$ & $0.105(0.075-0.174)$ & 1.84 & $2.1(1.5-3.0)^{*}$ \\
Chã Grande II-PE & 268 & 5 & $1.83 \pm 0.23 \mathrm{a}$ & $0.016(0.012-0.022)$ & $0.126(0.072-0.309)$ & 3.87 & $2.4(1.6-3.5)^{*}$ \\
Camocin-PE & 319 & 5 & $2.04 \pm 0.27 \mathrm{a}$ & $0.019(0.014-0.024)$ & $0.124(0.090-0.206)$ & 3.16 & $2.9(2.0-4.1)^{*}$ \\
Vargem Alta-ES & 297 & 5 & $2.25 \pm 0.26 \mathrm{a}$ & $0.019(0.015-0.023)$ & $0.103(0.077-0.158)$ & 1.96 & $2.9(2.0-4.0)^{*}$ \\
Garanhuns-PE & 327 & 5 & $1.83 \pm 0.23 \mathrm{a}$ & $0.022(0.018-0.027)$ & $0.174(0.115-0.331)$ & 4.16 & $3.3(2.4-4.6)^{*}$ \\
Bonito-PE & 264 & 5 & $2.61 \pm 0.31 \mathrm{~b}$ & $0.136(0.110-0.161)$ & $0.579(0.443-0.866)$ & 3.74 & $20.2(14.7-27.8)^{*}$ \\
\hline
\end{tabular}

${ }^{1}$ Number of insects bioassayed. ${ }^{2}$ Degree of Freedom. ${ }^{3}$ Standard Error. ${ }^{4}$ Chi Square $(p>0.05) .{ }^{5}$ Toxicity ratio - calculated between the estimated $\mathrm{LC}_{50}$ of susceptible and tolerant populations through Robertson and Preisler (1992) method. ${ }^{6} \mathrm{Confidence}$ interval at $95 \%$ of the toxicity ratio. ${ }^{*}$ Toxicity ratio significant (confidence interval does not include the value 1.0).

Table 3 - Susceptibility of Plutella xylostella populations to deltamethrin.

\begin{tabular}{lccccccc}
\hline Population & $\mathrm{n}^{(1)}$ & $\mathrm{DF}^{(2)}$ & Slope $\pm \mathrm{SE}^{(3)}$ & $\mathrm{LC}_{50}(\mathrm{CI} 95 \%) \mathrm{mg} \mathrm{L}^{-1}$ & $\mathrm{LC}_{95}(\mathrm{CI} 95 \%) \mathrm{mg} \mathrm{L}^{-1}$ & $\chi^{2(4)}$ & $\mathrm{TR}^{(5)}\left(\mathrm{CI}_{95} \%\right)^{(6)}$ \\
\hline Vargem Alta-ES & 320 & 6 & $3.50 \pm 0.35 \mathrm{~b}$ & $85.19(75.16-97.03)$ & $251.75(201.70-345.17)$ & 4.12 & - \\
Brasília-DF & 353 & 5 & $2.97 \pm 0.43 \mathrm{a}$ & $94.95(82.55-107.46)$ & $338.71(256.13-546.85)$ & 3.52 & $1.1(0.7-1.8)$ \\
Camocin-PE & 301 & 5 & $2.81 \pm 0.29 \mathrm{a}$ & $185.82(154.80-218.26)$ & $715.42(565.85-991.30)$ & 3.93 & $2.2(1.3-3.6)^{*}$ \\
Alegre-ES & 305 & 5 & $2.72 \pm 0.29 \mathrm{a}$ & $222.90(188.44-263.83)$ & $896.81(673.35-1361)$ & 1.43 & $2.6(0.8-8.8)$ \\
Chã Grande II-PE & 302 & 5 & $2.46 \pm 0.28 \mathrm{a}$ & $258.75(217.70-306.46)$ & $1204(878.58-1938)$ & 2.35 & $3.0(1.8-5.1)^{*}$ \\
Bonito-PE & 258 & 5 & $2.35 \pm 0.31 \mathrm{a}$ & $261.87(215.98-314.86)$ & $1311(917.48-2339)$ & 2.47 & $3.1(1.8-5.2)^{*}$ \\
Chã Grande I-PE & 313 & 5 & $2.43 \pm 0.28 \mathrm{a}$ & $276.76(234.29-327.51)$ & $1312(947.42-2150)$ & 3.39 & $3.3(1.0-10.2)^{*}$ \\
Garanhuns-PE & 376 & 5 & $3.01 \pm 0.36 \mathrm{a}$ & $360.10(317.22-411.38)$ & $1266(962.90-1938)$ & 2.27 & $4.2(2.6-7.0)^{*}$ \\
\hline
\end{tabular}

${ }^{1}$ Number of insects bioassayed. ${ }^{2}$ Degree of Freedom. ${ }^{3}$ Standard Error. ${ }^{4}$ Chi Square $(p>0.05) .{ }^{5}$ Toxicity ratio - calculated between the estimated $\mathrm{LC}_{50}$ of susceptible and tolerant populations through Robertson and Preisler (1992) method. ${ }^{6}$ Confidence interval at $95 \%$ of the toxicity ratio. *Toxicity ratio significant (confidence interval does not include the value 1.0). 
Table 4 - Susceptibility of Plutella xylostella populations to spinosad.

\begin{tabular}{lccccccc}
\hline Population & $\mathrm{n}^{(1)}$ & $\mathrm{DF}^{(2)}$ & Slope $\pm \mathrm{SE}^{(3)}$ & $\mathrm{LC}_{50}(\mathrm{CI} 95 \%) \mathrm{mg} \mathrm{L}^{-1}$ & $\mathrm{LC}_{95}(\mathrm{CI} 95 \%) \mathrm{mg} \mathrm{L}^{-1}$ & $\chi^{2(4)}$ & $\mathrm{TR}^{(5)}\left(\mathrm{CI}^{2} \%_{0}^{(6)}\right.$ \\
\hline Garanhuns-PE & 240 & 5 & $2.96 \pm 0.33 \mathrm{~b}$ & $0.014(0.012-0.017)$ & $0.052(0.040-0.075)$ & 1.96 & - \\
Chã Grande I-PE & 312 & 5 & $2.07 \pm 0.22 \mathrm{a}$ & $0.023(0.019-0.028)$ & $0.144(0.100-0.246)$ & 3.61 & $1.6(0.8-3.1)$ \\
Brasília-DF & 295 & 5 & $1.90 \pm 0.22 \mathrm{a}$ & $0.025(0.020-0.031)$ & $0.183(0.119-0.351)$ & 3.29 & $1.7(0.8-3.3)$ \\
Vargem Alta-ES & 273 & 5 & $3.75 \pm 0.41 \mathrm{~b}$ & $0.033(0.028-0.037)$ & $0.090(0.074-0.118)$ & 3.48 & $2.3(1.2-4.3)^{*}$ \\
Bonito-PE & 300 & 5 & $2.05 \pm 0.25 \mathrm{a}$ & $0.038(0.031-0.046)$ & $0.240(0.162-0.438)$ & 3.17 & $2.6(1.4-5.0)^{*}$ \\
Camocin-PE & 366 & 6 & $2.45 \pm 0.31 \mathrm{a}$ & $0.047(0.040-0.056)$ & $0.220(0.151-0.404)$ & 1.34 & $3.3(1.7-6.2)^{*}$ \\
Alegre-ES & 385 & 5 & $2.65 \pm 0.36 \mathrm{a}$ & $0.062(0.046-0.077)$ & $0.258(0.200-0.381)$ & 3.51 & $4.3(2.2-8.4)^{*}$ \\
Chã Grande II-PE & 318 & 5 & $1.99 \pm 0.24 \mathrm{a}$ & $0.074(0.060-0.090)$ & $0.496(0.346-0.863)$ & 2.53 & $5.1(2.7-9.9)^{*}$ \\
\hline
\end{tabular}

${ }^{1}$ Number of insects bioassayed. ${ }^{2}$ Degree of Freedom. ${ }^{3}$ Standard Error. ${ }^{4}$ Chi Square $(p>0.05) .{ }^{5}$ Toxicity ratio - calculated between the estimated $\mathrm{LC}_{50}$ of susceptible and tolerant populations through Robertson and Preisler (1992) method. ${ }^{6} \mathrm{Confidence}$ interval at $95 \%$ of the toxicity ratio. *Toxicity ratio significant (confidence interval does not include the value 1.0).

when compared with the most susceptible population (Chã Grande I - PE), which may indicate an onset of resistance. High resistance levels of diamondback moth to abamectin have been reported in areas of Malaysia (Sayyed et al., 2004), which suggests that Brazilian populations may also evolve quickly to resistance. Abamectin is not registered to control pests of Brassicaceae in Brazil. In spite of this, growers have used it in instances where other insecticides have showed control failures as in the Agreste region of Pernambuco State. Indeed, the area where the Bonito-PE population was collected, the farmer was spraying abamectin-based products to control the diamondback moth until few days before the colony collection. The indiscriminate use of this product may actually worsen the resistance problems in these regions, even before its eventual registration.

The observed toxicity ratio suggests that proactive monitoring and management programs need to be implemented to sustain the potential use of insecticides not yet registered to control P. xylostella in Brazil. Also, the resistance ratio of abamectin for Bonito-PE population may be an indicative that resistance frequencies are close to a critical value, requiring a particular attention to the use of this product in the area. The broad use of insect growth regulators (IGRs) in some regions, such as the Agreste of Pernambuco, may have contributed to the fast abamectin resistance evolution. Populations selected with tebufenozide in laboratory resulted in crossresistance to abamectin (Cao and Han, 2006). But, the results of the present work suggest that this hypothesis needs further investigation, because resistance to abamectin was restricted to a unique site. In fact, the other populations were particularly susceptible to it and toxicity ratio may reflect only the natural variability of those populations to abamectin.

The $\mathrm{LC}_{50}$ values for deltamethrin were very high $(85.2$ to $360.1 \mathrm{mg} \mathrm{L}^{-1}$ ) among the populations when compared with the field rate dosage, although the toxicity ratios to deltamethrin were low ( 2.2 - to 4.2 - fold), particularly because the lack of a general standard susceptible population of P. xylostella to this insecticide in this study
(Table 3). For instance, the Vargem Alta - ES population, the most susceptible population to deltamethrin, showed an $\mathrm{LC}_{50}$ of $85.2 \mathrm{mg} \mathrm{L}^{-1}$, which is about 11 -fold higher than the field rate dosage $\left(7.5 \mathrm{mg} \mathrm{L}^{-1}\right.$ of abamectin). Field rate dosage must be able to kill a high percentage, generally $95 \%$ of a pest population regardless of its population density (Knipling, 1979). This efficacy loss has been observed at several other places in Brazil (Castelo Branco et al., 2003) without a clear explanation, but it is associated with resistance evolution in the evaluated populations. The $\mathrm{LC}_{50}$ values showed that these P. xylostella populations have been subjected to high selection pressure with deltamethrin or other pyrethroids over many years. Indeed, control failures with pyrethroids have been a constant in many of those areas, particularly in the Pernambuco State, which has a long history of pyrethroids use, mainly deltamethrin. Possibly other pyrethroids have likely lost their efficacies towards local $P$. xylostella populations.

An important aspect of the pyrethroid resistance is its stability (Georghiou, 1983; Chen and Sun, 1986). Although this has not been assessed in this study, the Chã Grande I - PE population, with an $\mathrm{LC}_{50}$ of $276.8 \mathrm{mg} \mathrm{L}^{-1}$, which correspond to 39 times the field dosage rate, is a strong case to support that hypothesis, despite of its maintenance in laboratory without any insecticide selection pressure for about ten years. Nevertheless, Sayyed and Wright (2006) stated that the toxicity ratio to deltamethrin in a diamondback moth population decreased from 498 to $47 \mu \mathrm{g} \mathrm{mL} L^{-1}$, when they compared the generation $\mathrm{F}_{2}$ and $\mathrm{F}_{8}$. Therefore, it is likely that the $\mathrm{LC}_{50}$ for deltamethrin in the Chã Grande I - PE population was manyfold higher at the collection time.

Ten years after introduction of spinosad in Asia to control P. xylostella, Attique et al. (2006) and Khaliq et al. (2007) observed that toxicity ratios varied from 1.0to 12.0-fold, during survey for resistance in P. xylostella populations from Pakistan. Eziah et al. (2008) verified that Australian field populations of $P$. xylostella were susceptible to spinosad. In the present study, although five populations had toxicity ratios to spinosad (2.3 to 5.1 - fold), both field and laboratory populations sur- 
veyed were susceptible to the insecticide (Table 4). Lethal concentration $\left(\mathrm{LC}_{50}\right)$ values varied from $0.014 \mathrm{mg}$ $\mathrm{L}^{-1}$ (Garanhuns-PE) to $0.074 \mathrm{mg} \mathrm{L}^{-1}$ (Chã Grande II-PE), a 5.3-fold difference in susceptibility, which are very low values compared with the field dose rate $(120 \mathrm{mg}$ $\left.\mathrm{L}^{-1}\right)$. Additionally, these values are still below the discriminating dose $\left(10 \mathrm{mg} \mathrm{L}{ }^{-1}\right)$, which separate the SS and RS genotypes from RR genotype in P. xylostella (Zhao et al., 2002). These values possibly reflect the natural variability of populations when responding to spinosad, and particularly because the laboratory populations were never exposed to this insecticide. Despite this observation, resistance to spinosad has already been reported in many populations of $P$. xylostella worldwide (Sayyed et al., 2004; Zhao et al., 2002; Zhao et al., 2006), which suggests that spinosad use in Brazil must be cautiously pursued. Castelo Branco et al. (2003) obtained $100 \%$ mortality 72 hours after spraying $96 \mathrm{mg} \mathrm{L}^{-1}$ of spinosad on some Brazilian populations of the diamondback moth. Sayyed et al. (2004) reported that the majority of growers from Malaysia used to spray spinosad to control diamondback moth since the end of 1990 and, because of the high spinosad pressure towards this pest, up to 171 - fold toxicity ratio to spinosad was reported in Malaysian field populations (Sayyed and Wright, 2006). Additionally, insects from other orders such as Musca domestica (Shono and Scott, 2003) and Franklinella occidentalis have already been reported to resist to spinosad (Zhang et al., 2008). These authors suggest that resistance to spinosad can rapidly appear in diamondback moth populations from Brazil, and thus spinosad use must be monitored after its introduction. For a while, the high cost of spinosad may prevent growers from using it indiscriminately, therefore delaying the onset of resistance.

No evidence of cross-resistance among the evaluated insecticides was observed. There was no correlation between $\log \mathrm{LC}_{50} \mathrm{~s}$ of abamectin and deltamethrin ( $\mathrm{r}=$ $0.142 ; p>0.05, \mathrm{n}=8)$, abamectin and spinosad $(\mathrm{r}=$ $0.033 ; p>0.05, \mathrm{n}=8)$, and deltamethrin and spinosad $(\mathrm{r}=-0.060 ; p>0.05, \mathrm{n}=8)$. Same trend was observed for pairwise correlation analysis of $\log \mathrm{LC}_{95}$ s. Sayyed et al. (2005) showed no evidence of cross-resistance, neither between deltamethrin and spinosad nor between deltamethrin and abamectin. Therefore, rotational use of spinosad and abamectin, together with the current use of Bt-based products, can be applied in Brazilian areas where pyrethroids have failed in the control of $P$. xylostella. However, a monitoring program designed to detect changes in the susceptibility, which may result from repeated use and prolonged exposure to these insecticides under field conditions, will be essential to these insecticides long-term sustainability.

\section{Acknowledgements}

To CAPES for supporting the first author with the assistantship and financial aid through PROF/CAPES program.

\section{References}

Abbott, W.S. 1925. A method of computing the effectiveness of an insecticide. Journal of Economic Entomology 18: 265-267.

Araújo, A.C.P.; Nogueira, D.P.; Augusto, L.G.S. 2000. Pesticide impact on health: a study of tomato cultivation. Revista de Saúde Pública 34: 309-313. (in Portuguese, with abstract in English).

Attique, M.N.R.; Khaliq, A.; Sayyed, A.H. 2006. Could resistance to insecticides in Plutella xylostella (Lep., Plutellidae) be overcome by insecticide mixtures? Journal of Applied Entomology 130: 122-127.

Barros, R.; Vendramim, J.D. 1999. Influence of cabbage cultivars utilized for rearing of Plutella xylostella (L.) (Lepidoptera: Plutellidae) on the development of Trichogramma pretiosum Riley (Hymenoptera: Trichogrammatidae). Anais da Sociedade Entomologica do Brasil 28: 469-476. (in Portuguese, with abstract in English).

Cao, G.; Han, Z. 2006. Tebufenozide resistance selected in Plutella xylostella and its cross-resistance and fitness cost. Pest Management Science 62: 746-751.

Castelo Branco, M.; França, F.H.; Bôas, G.L.V. 1997. Diamondback Moth Plutella xylostella: Arthropods of Economic Importance. Embrapa Hortaliças, Brasília, DF, Brazil. (in Portuguese).

Castelo Branco, M.; França, F.H.; Medeiros, M.A.; Leal, J.G.T. 2001. Use of insecticides for controlling the South American Tomato Pinworm and the Diamondback Moth: a case study. Horticultura Brasileira 19: 60-63. (in Portuguese, with abstract in English).

Castelo Branco, M.; França, F.H.; Pontes, L.A.; Amaral, P.S.T. 2003. Forecasting insecticide susceptibility in Diamondback Moth populations from different areas of Brazil. Horticultura Brasileira 21: 549-552. (in Portuguese, with abstract in English).

Chen, J.S.; Sun, C.N. 1986. Resistance of diamondback moth (Lepidoptera: Plutellidae) to a combination of fenvalerate and piperonyl butoxide. Journal of Economic Entomology 79: 2230.

Eziah, V.Y.; Rose, H.A.; Clift, A.D.; Mansfield, S. 2008. Susceptibility of four field populations of the diamondback moth Plutella xylostella L. (Lepidoptera: Yponomeutidae) to six insecticides in the Sydney region, New South Wales, Australia. Australian Journal of Entomology 47: 355-360.

Finney, D.J. 1971. Probit Analysis. 3ed. Cambridge University Press, London, UK.

França, F.H.; Cordeiro, C.M.T.; Giordano, L.B.; Resende, A.M. 1985. Diamondback moth control in cabbage, 1984. Horticultura Brasileira 3: 47-53. (in Portuguese, with abstract in English).

França, F.H.; Medeiros, M.A. 1998. Impact of insecticide mixtures on the cabbage yield and the parasitoids of diamondback moth. Horticultura Brasileira 16: 132-135. (in Portuguese, with abstract in English).

Georghiou, G.P. 1983. Management of Resistance in Arthropods. In: Georghiou, G.P.; Saito, T. (eds.). Pest Resistance to Pesticides: Challenges and Prospects. New York, NY: Plenum Press, 1983. p. 769-792.

Guan-Soon, L. 1990. Overview of vegetable IPM in Asia. FAO Plant Protection Bulletin 38: 73-88.

Kabir, K.H.; Chapman, R.B.; Penman, D.R. 1993. Miticide bioassays with spider mites (acari: Tetranychidae): Effect of test method, exposure period and mortality criterion on the precision of response estimates. Experimental and Applied Acarology 17: 695-708.

Khaliq, A.; Attique, M.N.R.; Sayyed, A.H. 2007. Evidence for resistance to pyrethroids and organophosphates in Plutella xylostella (Lepidoptera: Plutellidae) from Pakistan. Bulletin of Entomological Research 97: 191-200.

Knipling, E.F. 1979. The basic principles of insect population suppression and management. USDA, Washington, DC, USA. (ESA Agricultural Handbook, 512). 
LeOra Software. 1987. POLO-PC: A User's Guide to Probit and Logit Analysis. LeOra Software, Berkeley, CA, USA.

Melo, P.E.; Branco, M.C.; Madeira, N.R. 1994. Cabbage genotypes assessement for resistance to diamondback moth. Horticultura Brasileira 12: 19-24. (in Portuguese, with abstract in English).

Oouchi, H. 2005. Insecticidal properties of a juvenoid, pyriproxyfen, on all life stages of the diamondback moth, Plutella xylostella (Lepidoptera: Yponomeutidae). Applied Entomology and Zoology 40: 145-149.

Robertson, J.L.; Preisler, H.K. 1992. Pesticide bioassays with arthropods. CRC Press, Boca Raton, FL, USA.

Sarfraz, M.; Keddie, B.A. 2005. Conserving the efficacy of insecticides against Plutella xylostella (L.) (Lep., Plutellidae). Journal of Applied Entomology 129: 149-157.

SAS Institute. 2001. SAS/STAT User's guide, version 8.02, TS level 2MO. SAS Institute, Cary, NC, USA.

Sayyed, A.H.; Attique, M.N.R.; Khaliq, A.; Wright, D.J. 2005. Inheritance of resistance and cross-resistance to deltamethrin in Plutella xylostella (Lepidoptera: Plutellidae) from Pakistan. Pest Management Science 61: 636-642.

Sayyed, A.H.; Omar, D.; Wright, D.J. 2004. Genetics of spinosad resistance in a multi-resistant field-selected population of Plutella xylostella. Pest Management Science 60: 827-832.

Sayyed, A.H.; Wright, D.J. 2006. Genetics and evidence for an esterase-associated mechanism of resistance to indoxacarb in a field population of diamondback moth (Lepidoptera: Plutellidae). Pest Management Science 62: 1045-1051.

Shelton, A.M.; Robertson, J.L.; Tang, J.D.; Perez, C.; Eigenbrode, S.D.; Priesler, H.K.; Wilsey, W.T.; Cooley, R.J. 1993. Resistance of Diamondback moth (Lepidoptera: Plutellidae) to Bacillus thuringiensis subspecies in the field. Journal of Economic Entomology 86: 697-705.

Shelton, A.M.; Sances, F.V.; Hawley, J.; Tang, J.D.; Boune, M.; Jungers, D.; Collins, H.L.; Farias, J. 2000. Assessment of insecticide resistance after the outbreak of diamondback moth (Lepidoptera: Plutellidae) in California in 1997. Journal of Economic Entomology 93: 931-936.
Shono, T.; Scott, J.F. 2003. Spinosad resistance in the housefly Musca domestica (Diptera: Muscidae) is due to a recessive factor on autosome 1. Pesticide Biochemistry and Physiology 75: 1-7. Sokal, R.R.; Rohlf, F.J. 1995. Biometry. 3ed. Freeman, New York, NY. USA.

Talekar, N.S.; Shelton, A.M. 1993. Biology, Ecology, and Management of the Diamondback Moth. Annual Review of Entomology 38: 275-301.

Wilson, H.P.; Kuhar, T.P.; Rideout, S.L.; Freeman, J.H.; Reiter, M.; Straw, R.A.; Hines, T.E.; Waldenmaier, C.M.; Doughty, H.B.; Deitch, U.T.; Aigner, J.D. 2006. Commercial vegetable production recommendations. Virginia Cooperative Extension. Available at: http://www.ext.vt.edu/pubs/vegetables/456-420/ 456-420.html. [Accessed Jan. 10, 2009].

Zhang, S.Y.; Kono, S.; Murai, T.; Miyata, T. 2008. Mechanisms of resistance to spinosad in the western flower thrip, Frankliniella occidentalis (Pergande) (Thysanoptera: Thripidae). Insect Science 15: 125-132.

Zhao, J.Z.; Collins, H.L.; Li, Y.X.; Mau, R.F.L.; Thompson, G.D.; Hertlein, M.; Andaloro, J.T.; Boykin, R.; Shelton, A.M. 2006. Monitoring diamondback moth (Lepidoptera: Plutellidae) resistance to spinosad, indoxacarb, and emamectin benzoate. Journal of Economic Entomology 99: 176-181.

Zhao, J.Z.; Li, Y.X.; Collins, H.L.; Gusukuma-Minuto, L.; Mau, R.F.L.; Thompson, G.D.; Shelton, A.M. 2002. Monitoring and characterization of diamondback moth (Lepidoptera: Plutellidae) resistance to spinosad. Journal of Economic Entomology 95: 430-436.

Received November 27, 2009

Accepted August 25, 2010 